\title{
Effect of Plant Based Essential Oil on Immune Response of Silkworm, Antheraea assama Westwood (Lepidoptera: Saturniidae)
}

\author{
Bulbuli Khanikor* and Dipsikha Bora \\ Department of Life Sciences, Dibrugarh University, Assam, PIN.786004, India.
}

(Received 23 February 2012; Accepted 4 October 2012)

Botanicals have been regarded as sustainable solution of pest control because of their nominal effect on nontarget pest, biodegradability and other environment friendly properties. However, study on impact of botanicals against beneficial insects is less. In this investigation effort has been made to study the effect of essential oils of Ocimum sanctum, Ocimum gratissimum and Ageratum conyzoides against non-mulberry silkworm Antheraea assama in terms of percent mortality, total haemocyte count (THC) and phenol oxidase (PO) enzyme activity. After application of essential oil of the plants by contact residual film technique, age dependent decrease of percent mortality was recorded. Topical treatment of oil at higher dosages $\left(1 \mu \mathrm{lg}^{-1}\right.$ and $\left.0.5 \mu \mathrm{lg}^{-1}\right)$ caused $100 \%$ mortality of late instar larvae at 24 hour but the lowest dose $\left(0.25 \mu \mathrm{lg}^{-1}\right)$ did not cause any mortality till 48 hour of treatment. Initial increase of total haemocyte count (THC) was recorded at early hours of treatment (0.25 hour) at all dosages $\left(1,0.5,0.25 \mu \mathrm{lg}^{-1}\right)$ after topical treatment. A dose dependent increase was observed in phenol oxidase enzyme activity and this might indicate ability of the essential oils to cause induction of immune response in Antheraea assama larvae.

Key words: Antheraea assama, Phenoloxidase, Haemocyte, Ocimum sanctum, Ocimum gratissimum, Ageratum conyzoides

\footnotetext{
*To whom the correspondence addressed

Department of Life Sciences, Dibrugarh University, Assam786004, India.

Fax: +91-373-2370323;

E-mail: khanikorbulbuli@yahoo.co.in/ dipsikhabora03@yahoo.com

http://dx.doi.org/10.7852/ijie.2012.25.2.139
}

\section{Introduction}

Although botanicals can be used in environment friendly way of pest mangement, effort has not been made yet to use botanicals in host plant garden of Antheraea assama Westwood, producer of the golden yellow muga silk. Use of chemicals in host plant garden of muga silk worm is rare as the larvae are reared in outdoor condition. Moreover, A.assama larvae are very much susceptible to synthetic chemical pesticides even at very low dosages. Therefore botanicals are the possible alternatives to be used for the management of pests and parasitoids of silkworm. Ageratum and Ocimum spp. possess long history of traditional use as medicinal and insecticidal plants. Farmers of Assam also use Ocimum leaf water as a holy substance on egg bunch (Kharika) of A.assama without any report of adverse effect on larvae. The plants Ageratum conyzoides, Ocimum sanctum and Ocimum gratissimum have been found to be effective against Exorista sorbillans, a parasitoid of the silk worm (Bora et al., 2010 ; Bora and Khanikor, 2011) which causes 20-80\% loss in silk cocoon production round the year. Before exploring the possibility of using them as botanical pesticide in sericulture garden, it is essential to understand how does the silkworm respond to the effect of those botanicals. It has been well documented that insect haemocytes mediate immune response in invertebrates on presence of foreign material, toxin and microorganisms (Gupta, 1991; Pathak, 1993 ) and the response is exhibited in terms of phagocytosis in case of small sized particle and encapsulation and nodulation in case of large sized material and pathogens (Gillespie and Kanost, 1997). In addition defensin and phenoloxidase are two important protein molecules involved in insect immunity (Pathak, 1993; Hillyer and Christensen, 2005; Liu et al., 2009). Phenoloxidase located in cuticle, haemolymph and oenocyte is involved in sequential conversion of dopa into melanin and thus helps in the fight against nonself. If phenoloxidase plays 
important role in development of resistance against specific insecticides (Liu et al., 2009) or can act as indicator for immunocompetence in host-parasite model system (Pauwels et al., 2011), phenoloxidase activity may be used as a marker for evaluating toxic action as well. Therefore the possible effect of the plants in question were attempted to be evaluated through studies on effect of the plant's essential oil on percent mortality, total haemocyte count and phenoloxidase enzyme activity.

\section{Materials and Methods}

\section{Experimental animal}

DFL (Disease Free Layings) of Antheraea assama Westwood (Lepidoptera: Saturniidae) were brought from Govt. Sericulture Farm of Assam and kept in formalin washed $(2 \%)$ plastic tray. Newly hatched larvae were maintained by providing fresh tender leaves of host plant Sualo (Litchea polyantha). Moisture was provided by covering the tray with transparent polythene paper. From third instar onwards larvae were maintained in host plants grown in the garden of Department of Life Sciences, Dibrugarh University, Assam.

\section{Extraction of oil}

Fresh leaves were collected and washed in tap water to remove dust particles or other debris. The leaves were then chopped into fine pieces and hydrodistilled by using Clevanger apparatus (Denny,1989 ). After 4 hours of distillation the essential oil was separated from the surface of water. The oil was dried over anhydrous sodium sulphate. The sample was sealed and kept in dark glass vial in refrigerator for treatment.

\section{Effect on percent survival of A.assama larvae}

Bioassay of crude oil on early (E) and late (L) instar larvae of $A$. assama was carried out by contact residual film technique by using 0.01 to $0.5 \%$ concentration of oil extracted from the plants. The solutions were prepared in acetone. $1.5 \mathrm{ml}$ of oil solution was applied per replication to Whatman filter paper in the petriplate and allowed to dry the solvent for five minutes. A. assama larvae were then released in the treated plate in room temperature (19$32^{\circ} \mathrm{C}$, RH 56-82\%). Only acetone was applied for the control against each test concentration. Second day old larvae were used in each case. Observation was made at $1 \mathrm{~h}, 3 \mathrm{~h}$, $6 \mathrm{~h}, 24 \mathrm{~h}, 30 \mathrm{~h}, 48 \mathrm{~h}$ of treatment.

Topical bioassay of essential oil of selected plants were carried out by applying $1,0.5$ and $0.25 \mu \mathrm{gg}^{-1}$ of oil on late instar larvae and mortality as well as survival was recorded at $1 \mathrm{~h}, 3 \mathrm{~h}, 6 \mathrm{~h}, 24 \mathrm{~h}, 30 \mathrm{~h}, 48 \mathrm{~h}$ of treatment.
Abbott's correction factor (Abbott, 1925) was considered before computing percent survival of larvae.

\section{Effect on total haemocyte count}

Total haemocyte count of late larval instar was done after treatment with oil extracted from A.conyzoides, O.sanctum and O.gratissimum at the dose of $0.25,0.5$ and $1 \mu \mathrm{l} / \mathrm{g}$ body weight. Haemocyte count was done by the method modified after Gupta (1991).

Live insect was dipped into water maintained at $60^{\circ} \mathrm{C}$ for $5 \mathrm{~min}$. Then the larva was taken out of water and proleg was cut to draw the haemolymph. The first few drops of haemolymph was collected in a cavity block and quickly drawn into Thoma WBC pipette upto 0.5 mark. The physiological saline was sucked upto the 11th mark and was vigorously shaken for 3 minutes .The mixture was then carefully, poured on Neubauer haemocytometer. Observation of cell was done under Olympus light microscope at 40X. Manduca's physiological saline (Dean et al., 2004) was used for total haemocyte count. The composition of the saline was $4 \mathrm{mM} \mathrm{NaCl} ; 40 \mathrm{Mm} \mathrm{KCl} ; 18 \mathrm{Mm}$ $\mathrm{MgCl}_{2}$. $6 \mathrm{H}_{2} \mathrm{O} ; 1.5 \mathrm{mM} \mathrm{Na} \mathrm{HPO}_{4} ; 1.5 \mathrm{mM} \mathrm{NaH} \mathrm{PO}_{4}$, $192.8 \mathrm{mM}$ Sucrose; $0.05 \mathrm{~g}$ Gentian violet. Cells present in the four large squares in the four corners and in the central large square were counted. Each large square has a surface area of one square $\mathrm{mm}$. So total cells present in one square $\mathrm{mm}\left(\mathrm{THC} / \mathrm{mm}^{3}\right)$ was calculated by using the following formula

$\mathrm{THC} / \mathrm{mm}^{3}=\frac{\mathrm{X} \times 10 \times \mathrm{Y}}{5}$

$\mathrm{X}=$ Total cells present in 5 large squares.

$\mathrm{Y}=$ Dilution $=20$ times.

$10=$ Depth of chamber.

For each treatment, three replication was maintained and there was control to have the normal haemocyte count.

\section{Effect on phenoloxidase}

Late instar larvae of Antheraea assama were topically applied with three dosages of essential oils of the three plants (1.0, 0.5 and $0.25 \mu \mathrm{lg}^{-1}$ body weight of insects) to study their effect on phenoloxidase activity by using the method of Mucklow et al. (2004). L-Dopa (Merck-Germany) was used as substrate. PO activity was equivalent to dopachrome production which was the product of the oxidation of L-Dopa by the enzyme PO. Absorbance of Dopachrome was observed at $475 \mathrm{~nm}$ using UV-Visible spectrophotometer. $1 \mu \mathrm{l}$ of haemolymph was drawn in to micropipette by cutting the forelegs of the treated larvae and poured into the cuvette containing $150 \mu \mathrm{l}$ of phosphate-buffered saline (PBS). The composition of PBS was 


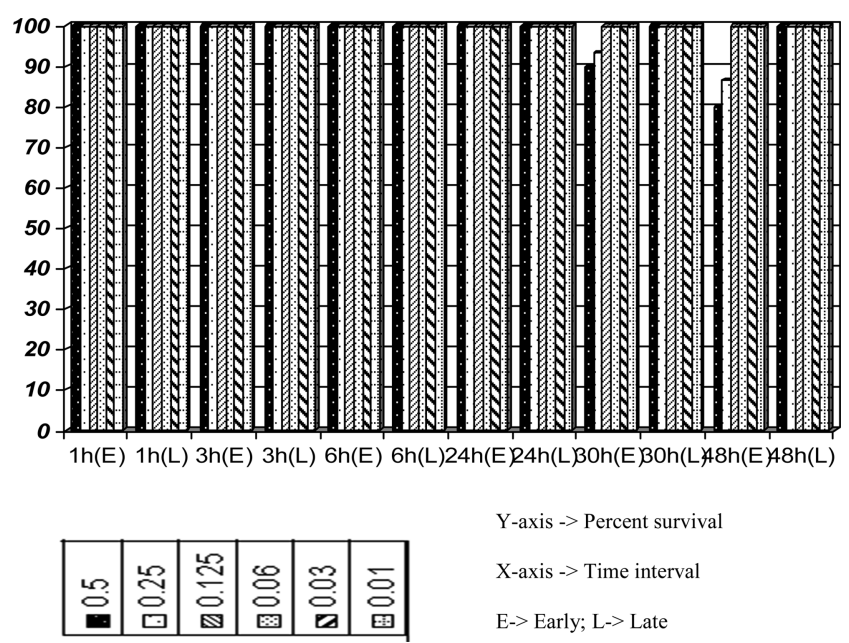

Fig. 1. Effect of essential oil of $O$. sanctum on percent survival (Mean) of early (E) \& late (L) instar larvae of $A$. assama (CRF).

$0.15 \mathrm{M}$ of $\mathrm{NaCl}, 10 \mathrm{mM}$ of $\mathrm{Na}_{2} \mathrm{HPO}_{4} .2 \mathrm{H}_{2} \mathrm{O}$ at $\mathrm{pH} 7.4$ with o-phosphoric acid. Then $450 \mu \mathrm{l}$ of $20 \mathrm{Mm}$ Dopa was added in the cuvette and absorbance was measured in the spectrophotometer. Absorbance was recorded immediately after adding the L-Dopa and every 15 minutes upto 1h using the same cuvette. Against each treatment, in nonhaemolymph controls containing only L-Dopa and PBS, the activity was measured and this activity of the nonhaemolymph control was subtracted from the activity of PO obtained in treated haemolymph. Change of PO activity of haemolymph without treatment was also measured. PO activity estimates were then calculated from the change in absorbance over the $1 \mathrm{~h}$ time period (absorbance after $1 \mathrm{~h}-$ absorbance at time 0 ). Enzyme activity was studied at $15 \mathrm{~min}, 1 \mathrm{~h}, 3 \mathrm{~h}$ and $6 \mathrm{~h}$ interval after treatment.

\section{Statistical analysis}

Percent mortality was expressed in mean \pm standard error (SE). Significance was evaluated using Paired t-test in THC and phenoloxidase enzyme activity experiments $(\mathrm{P}<0.05$ was considered significant).

\section{Results}

Application of $O$. sanctum essential oil to early instar larvae did not cause any mortality at lower concentrations. At higher concentrations $(0.50$ and $0.25 \%)$ onset time of mortality was 30 h. $0.50 \%$ concentration caused $10 \%$ and $20 \%$ mortality at $30 \mathrm{~h}$ and $48 \mathrm{~h}$ respectively while $0.25 \%$ concentration caused $6.67 \%$ and $13.34 \%$ mortality at $30 \mathrm{~h}$ and $48 \mathrm{~h}$ respectively (Fig. 1). For essential oil of $O$. grat-

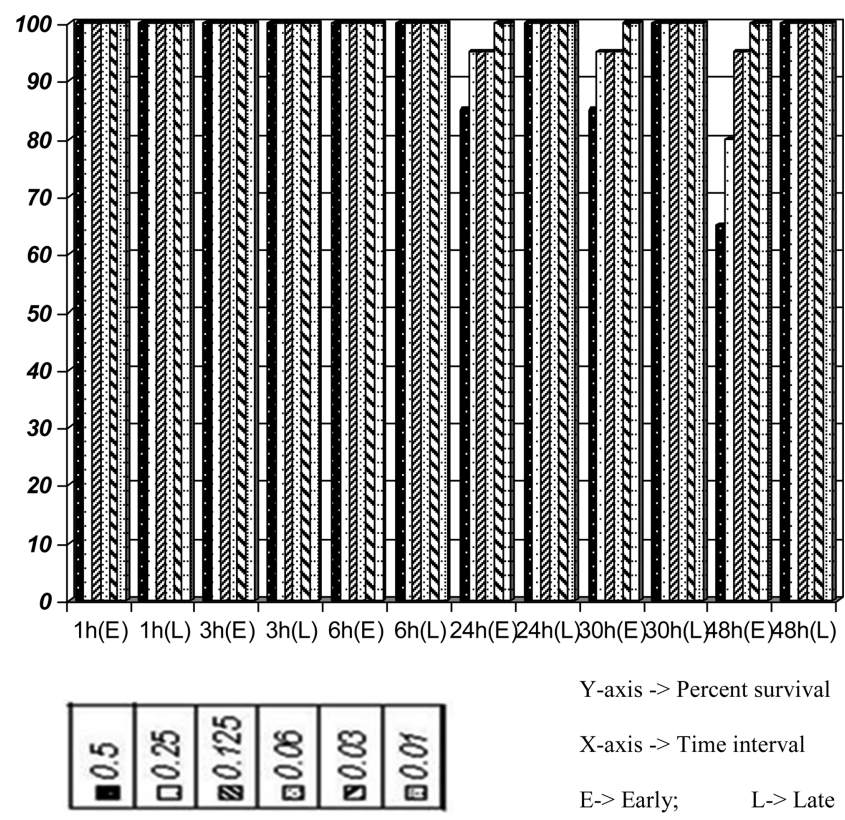

Fig. 2. Effect of essential oil of $O$. gratissimum on percent survival (Mean) of early (E) \& late (L) instar larvae of $A$. assama (CRF).

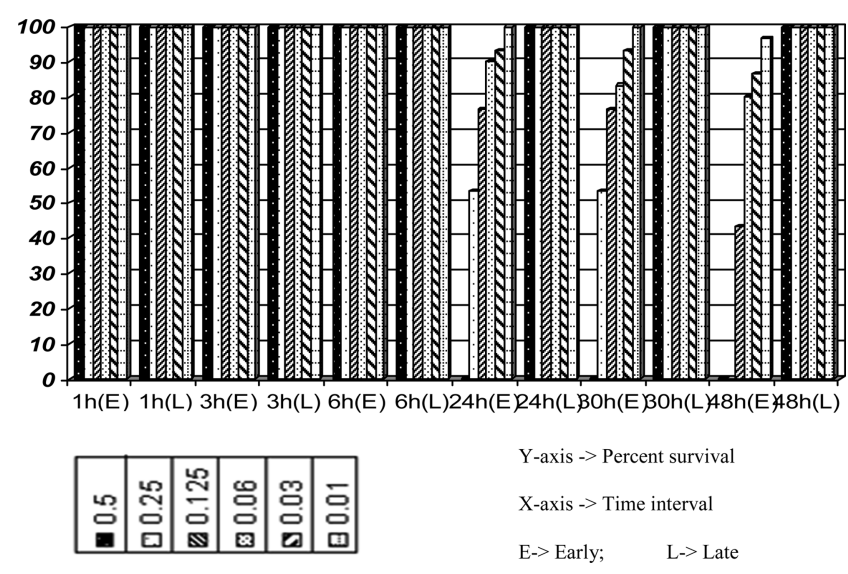

Fig. 3. Effect of essential oil of A. conyzoides on percent survival (Mean) of early (E) and late (L) instar larvae of $A$. assama (CRF).

issimum, onset time of mortality was $24 \mathrm{~h}$ at $0.06,0.125$, $0.25,0.5 \%$ concentrations. Percent mortality was higher at $0.5 \%$ (maximum $35 \%$ at $48 \mathrm{~h}$ ) and $0.25 \%$ (maximum $20 \%$ at $48 \mathrm{~h}$ ) in comparison to those of $O$. sanctum (Fig. 1 and 2 ). For essential oil of $A$. conyzoides, onset time of mortality was $48 \mathrm{~h}$ at the lowest concentration $(0.06 \%)$ and $24 \mathrm{~h}$ for the rest of the concentrations. $0.50 \%$ and $0.25 \%$ concentration caused $100 \%$ mortality at $24 \mathrm{~h}$ and $48 \mathrm{~h}$ respectively (Fig. 3). LC50 of A.conyzoides oil was $0.19 \%$ (Fig. 4) $\left(\mathrm{Y}=7.11+2.92 \mathrm{X}\right.$; R.Sq=0.989; $\chi^{2}=172.24$; Fiducial limit $=2.394-2.837)$ while the same could not be com- 


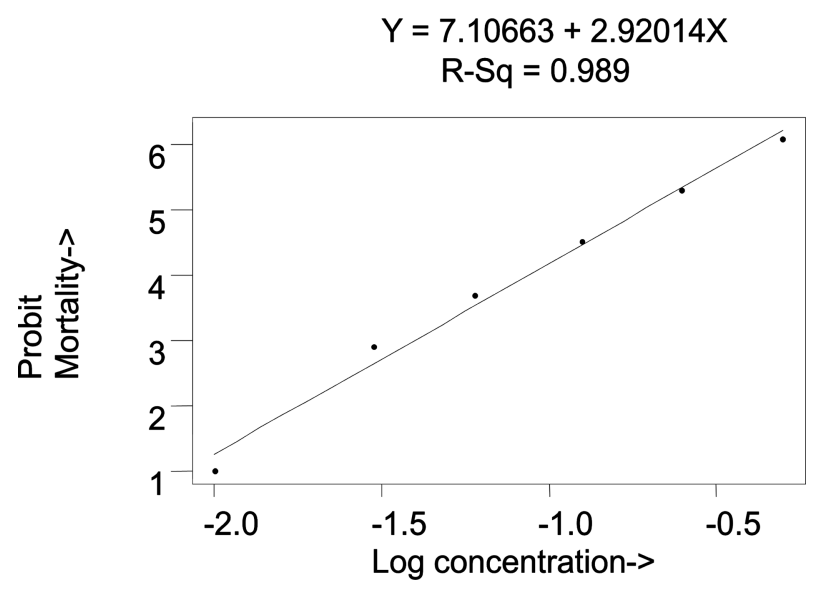

Fig. 4. Regression plot of probit mortality of A. assama early instar larvae against $\log$ concentration of essential oil of $A$. conyzoides.

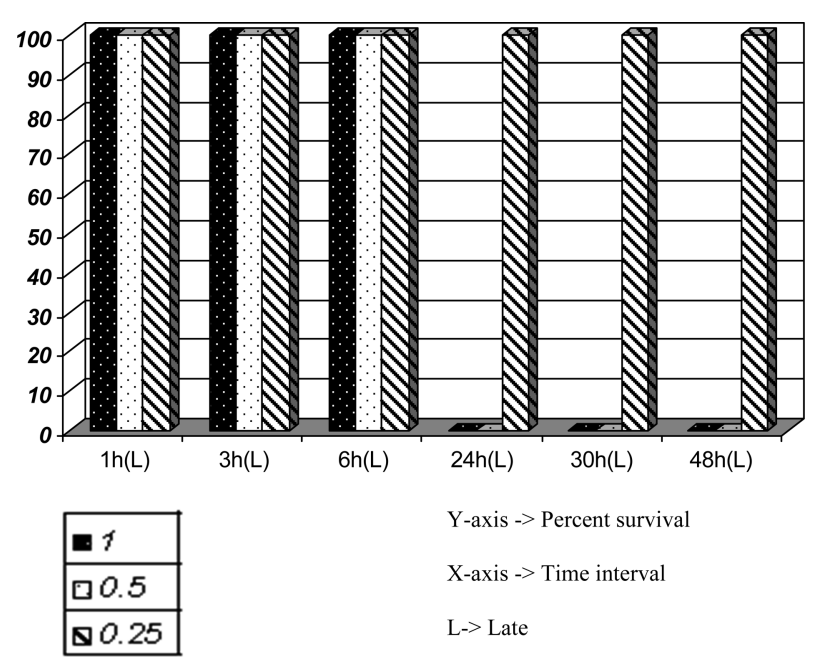

Fig. 5. Effect of essential oil of selected plants on percent mortality of late instar larvae of A. assama (Topical application).

puted for Ocimum spp. for their low toxicity against the silkworm larvae. The results reflected higher toxicity of $A$. conyzoides essential oil against early instar larvae and the order of toxicity of essential oil of these three plants can be shown as O.sanctum $<$ O.gratisimum $<$ A.conyzoides. However $100 \%$ survival of late instar larvae was recorded till $48 \mathrm{~h}$ at all the concentrations. After topical application of essential oil of the plants, the higher dosages were found toxic to the late instar silk worm larvae (Fig. 5). Application of the oil at the dosages of 1.0 and $0.5 \mu \mathrm{gg}^{-1}$ resulted in $100 \%$ mortality of larvae at $24 \mathrm{~h}$ of treatment while larvae survived till $48 \mathrm{~h}$ at the lowest dose $\left(0.25 \mu \mathrm{gg}^{-1}\right)$. These three toxic dosages were considered for study in order to assess response of immune system of $A$. assama in terms of total haemocyte count and phenoloxidase

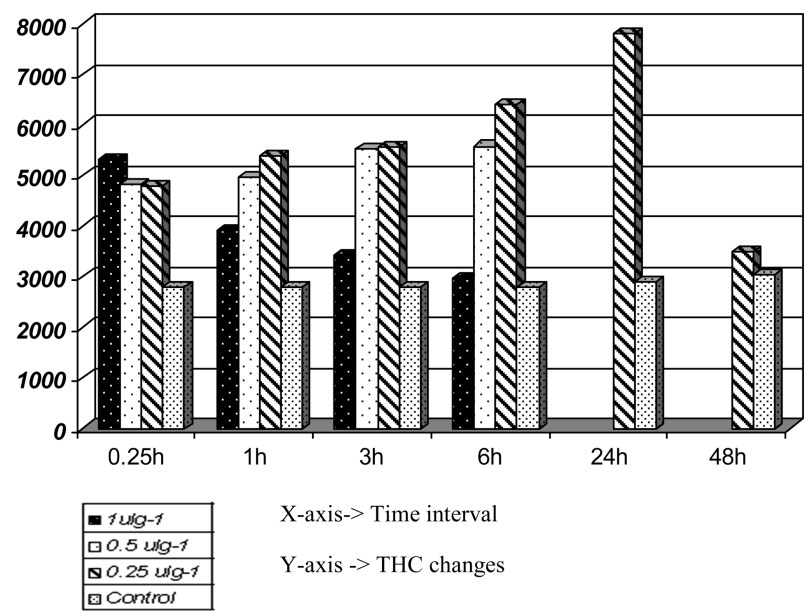

Fig. 6. Variation of THC in A. assama larvae after treatment of essential oil of $O$. sanctum.

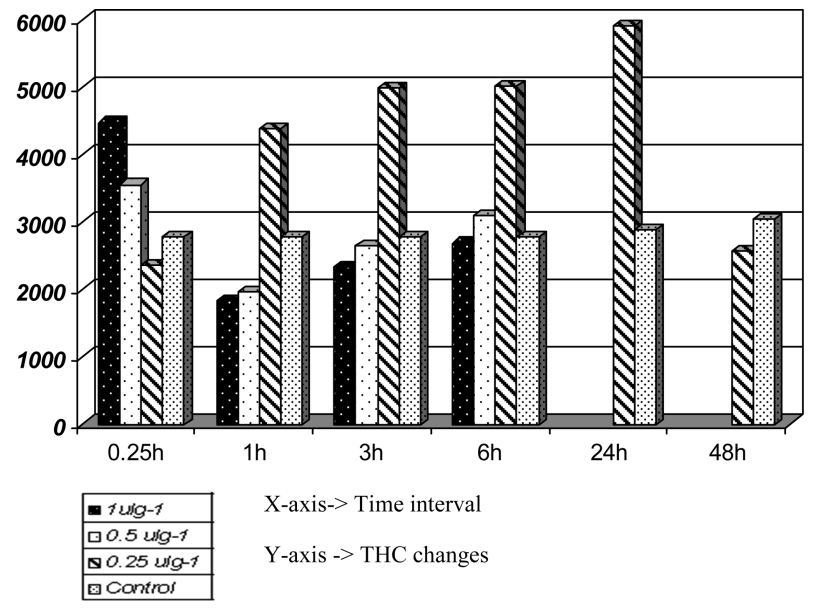

Fig. 7. Variation of THC in A. assama larvae after treatment of essential oil of $O$. gratissimum.

enzyme activity.

On application of essential oil of $O$. sanctum at a dose of $1 \mu \mathrm{g}^{-1}$ on $A$. assama larvae, THC significantly increased at $0.25 \mathrm{~h}\left(5320 \pm 180^{*}\right)$ and $1 \mathrm{~h}\left(3924 \pm 71^{*}\right)$ which then came down to the level of control( $2782 \pm 213)$ at $3 \mathrm{~h}$ and $6 \mathrm{~h}$. On application of $0.5 \mu \mathrm{lg}^{-1}$ oil, THC increased significantly from $0.25 \mathrm{~h}$ onwards. $O$. sanctum oil at a dose of $0.25 \mu \mathrm{gg}^{-1}$ enhanced THC significantly till $48 \mathrm{~h}$ (Fig. 6). Application of $1 \mu \mathrm{gg}^{-1}$ of essential oil of O. gratissimum on A. assama larvae initially increased THC level at $0.25 \mathrm{~h}\left(4472 \pm 4^{*}\right)$ and then significantly decreased at $1 \mathrm{~h}\left(1828 \pm 14^{*}\right)$. THC then became at par with control at $3 \mathrm{~h}$ and $6 \mathrm{~h}$. At the dose of $0.5 \mu \mathrm{gg}^{-1}$, initial rise of THC occurring at $0.25 \mathrm{~h}$ was followed by a significant decrease at $1 \mathrm{~h}$ of treatment. THC again significantly rose at $6 \mathrm{~h}$. Application of $0.25 \mu \mathrm{lg}^{-1}$ showed significant rise of THC from $1 \mathrm{~h}$ till 


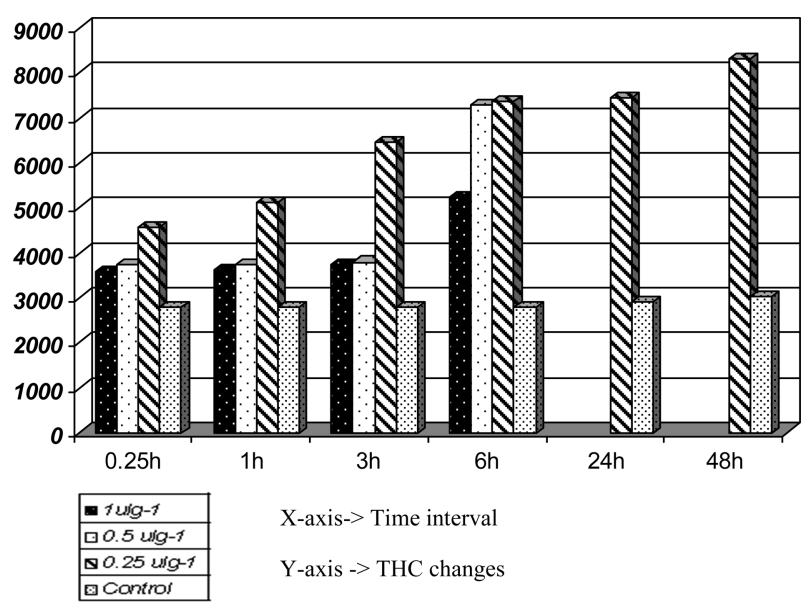

Fig. 8. Variation of THC in A. assama larvae after treatment of essential oil of $A$. conyzoides.

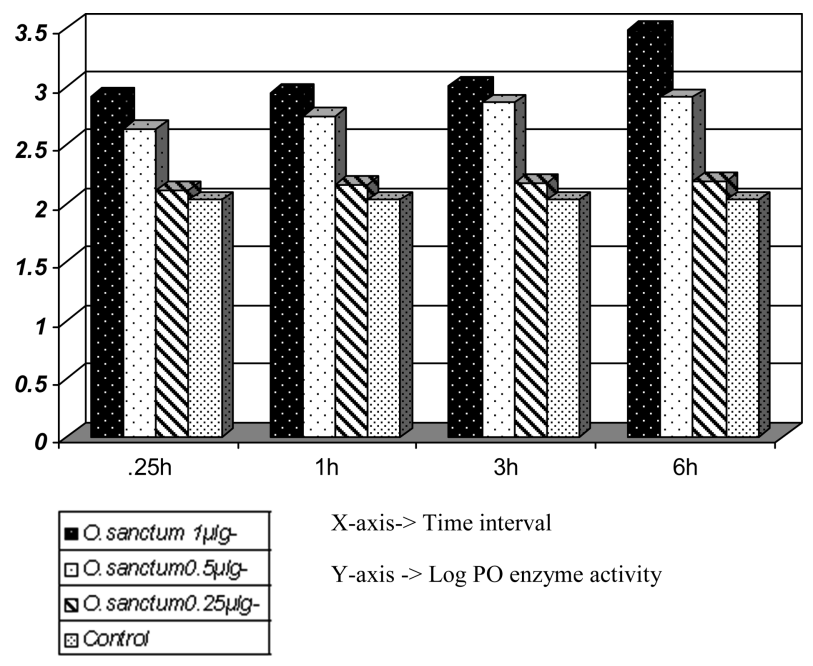

Fig. 9. Variation of log phenol oxidase enzyme activity in $A$. assama larvae after treatment of essential oil of $O$. sanctum.

$24 \mathrm{~h}$ while at $48 \mathrm{~h}$ of treatment THC decreased significantly (Fig. 7). Application of essential oil of $A$. conyzoides at a dose of $1 \mu \mathrm{lg}^{-1}$ and $0.5 \mu \mathrm{lg}^{-1}$ caused significant rise of THC from $0.25 \mathrm{~h}$ to $6 \mathrm{~h}$ of treatment (Fig. 8). Application at the dose of $0.25 \mu \mathrm{lg}^{-1}$ enhanced THC till $48 \mathrm{~h}$.

Results presented in the Fig (9-11) showed that there was dose dependent increase in enzyme activity. After application of $1 \mu \mathrm{lg}^{-1}$ and $0.5 \mu \mathrm{lg}^{-1}$ dose , the essential oil of $O$. sanctum, $O$. gratissimum and $A$. conyzoides enhanced PO activity in treated larvae in comparison to control larvae. But after application of the lowest dose $\left(0.25 \mu \mathrm{lg}^{-1}\right)$ of the three oil types variation of phenoloxidase enzyme activity was found to be not significantly differed from that of control.

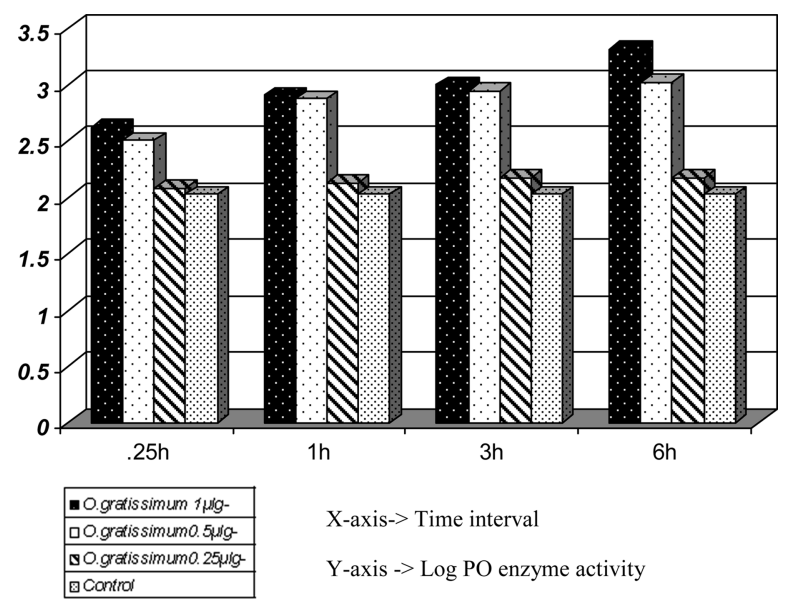

Fig. 10. Variation of $\log$ phenol oxidase enzyme activity in $A$. assama larvae after treatment of essential oil of $O$. gratissimum.

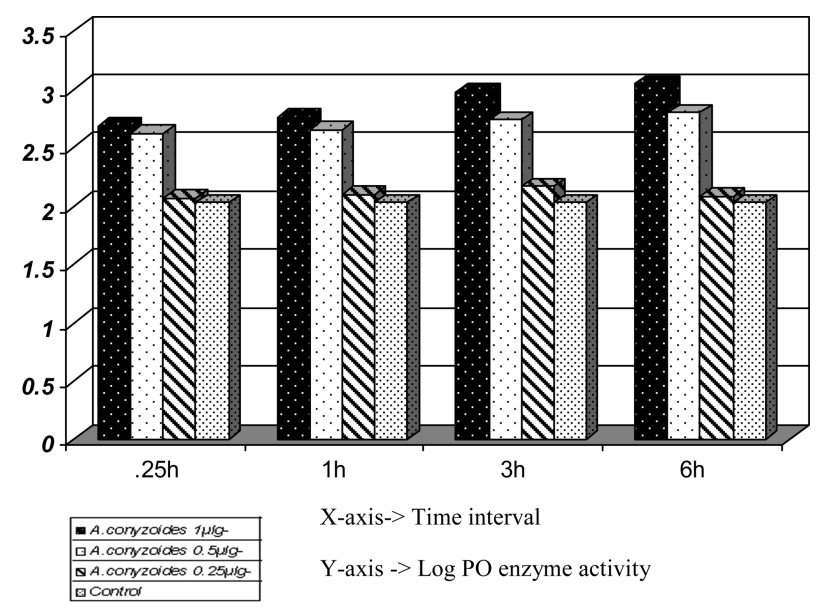

Fig. 11. Variation of $\log$ phenol oxidase enzyme activity in $A$. assama larvae after treatment of essential oil of $A$. conyzoides.

\section{Discussion}

The results showed that out of the three plants, the essential oil of A. conyzoides was the most toxic. The study further revealed that while early instar larvae were susceptible to the action of essential oils, late instar larvae were resistant and could survive after exposure to oil treatments. Such resistance of late larval instars of $A$. assama to the essential oil under consideration may be attributed to age dependent changes in bioconstituents. Insecticides upon entering insect body may be acted upon by detoxifying enzyme system for detoxification before they reach the site of action. Age dependent changes in enzyme activity and their subsequent correlation with insecticide toxicity have been reported for several insects with respect to cyto- 
chrome P450, glutathione S-transferase, malathion carboxylesterase and microsomal oxidase enzyme (Yu 1983; Gui et al., 2009; Lee et al., 1996; Rajatileka et al., 2011).

THC is correlated with the rate of phenomena occurring during insect immune response such as phagocytosis, nodule formation, encapsulation, recognition of foreign bodies and wound healing and hence the total number of haemocytes reflect the involvement of immune system to deal with pathogens or chemical molecules (Kraaijeveld et al., 2001). In the present investigation, increase of THC at early hours of treatment at all dosages and at all hours at the lowest dose on treatment with essential oil of $O$. sanctum, $O$. gratissimum and A. conyzoides might reflect activation of immune response. Rapid haemocyte division to encounter with the nonself oil compounds may enhance THC. Starvation resulting in low haemolymph volume was considered a reason of increasing THC in Prodenia eridenia larva (Rosenberger and Jones, 1960; Sharma et al. 2008). The ups and subsequent down regulation of THC level occurring on application of essential oil might suggest an active involvement of the defense system to overcome the toxic action in which the haemocytes in the circulation have been used up for the purpose of defense. At sub lethal dose $\left(0.25 \mu \mathrm{lg}^{-1}\right)$, although at $24 \mathrm{~h}$ post treatment THC was high in cases of all the oil, at $48 \mathrm{~h}$ in response to action of $O$. gratissimum THC decreased. Greater stress of $O$. gratissimum was also evident at the time of topical application when it caused immediate shrinkage of integument and darkening of the area of application and vigorous jerking of anterior body part which were not observed on application of the other oils. In case of treatment with both $O$. gratissimum and $A$. conyzoides, greater amount of regurgitants were observed which is considered as symptom of toxicity (Matsumura,1980). Initial increase followed by decrease in THC, 12-72 $\mathrm{h}$ post treatment of insecticides were reported by several workers (Sharma et al.2008; Qadri and Narsaiah, 1978; Ayyangar and Rao, 1990; El-Aziz and Awad, 2010; Prasada Rao et al., 1984). THC is also dependent on ecdyson titre Prasada Rao et al., 1984; Ayyangar and Rao, 1990). Insecticide like abamectin induced release of antidiuretic hormone from neurosecretory cells of the thoracico-abdominal ganglionic mass that slowed down the rate of excretion resulting in increase of blood volume and thereby decrease of total haemocyte count (Suhail et al., 2007). Reduction of haemocytes may also be due to disturbance caused in haemopoetic organs which are responsible for production of haemocytes (Tiwari et al., 2002). Decrease in haemocyte on application of insecticidal chemical after $12 \mathrm{~h}$ and $24 \mathrm{~h}$ of treatment was reported in other insects also (Qadri and Narsaiah, 1978; Ayyangar and Rao, 1990; El-Aziz and Awad, 2010).
Phenoloxidase enzyme plays an important role in nonself recognition and thereby confers immunity against exogenous chemicals, parasites, parasitoids and pathogens in various arthropods (Ratcliffe et al., 1984; Marmaras et al., 1996; Ashida and Brey, 1997; Shelby, 2000; Shiao et al., 2001; Mucklow and Ebert, 2003; Yu et al., 2003; Ling et al., 2005; Zhu et al., 2009). The lowest dose of the essential oil of the selected plants could not induce phenoloxidase activity in Antheraea assama larvae while the higher dosages significantly enhanced the enzyme activity than that of control larvae. This is the first report of activation of phenol oxidase enzyme activity in Antheraea assama after oil treatment. Phenoloxidase occurs as an inactive proenzyme i.e. prophenoloxidase in the haemolymph of insects including silkworm Bombyx mori and Antheraea pernyi (Nappi and Sugumaran, 1993). Phenoloxidase enzyme converts tyrosine into Dopa which is used in synthesis of melanin for subsequent use in wound healing and immune response (Huang et al., 2002). Increase in phenoloxidase activity has long been correlated with increased resistance to pathogen (Brookman et al., 1989; Soderhall and Cerenius, 1998; Sugumaran, 2002; Shelby and Popham, 2006) and decrease of phenoloxidase activity is attributed to weakening of immune system (Hiromori and Nishigaki, 2001). In addition to pathogens, the system is also activated in response to presence of other nonself materials like chemical insecticide, glass beads etc (Pathak, 1993; Liu et al., 2009). Activation of PO activity confers resistance against invading nonself material, but it may not always adequately reflect overall resistance against all insults (Schwarzenbach and Ward, 2007). Although consistent measurement of phenoloxidase activity and haemocyte count have been successfully used in immunity studies in insects (Schwarzenbach and Ward, 2007; Lourenco et al., 2005; Schmid et al., 2008), study of immune related gene expression in haemolymph and fat bodies responsible for conferring immunity are required to understand the complex mechanism of immune response occurring in response to oil treatment (Fang et al., 2010).

\section{Acknowledgement}

The authors are thankful to University Grants Commission for funding the project F.No-32-471/2006(SR)for carrying out the work.

\section{References}

Abbott WS (1925) A method of computing the effectiveness of an insecticide. J Econ Entomol 18, 265-267. 
Ashida M, Brey PT (1997) Recent advances in research on the insect prophenoloxidase cascade, in Molecular Mechanisms of Immune Responses In Insects, pp. 132-172, Chapman Hall, London.

Ayyangar GSG, Rao PJ (1990) Changes in haemolymph constituents of Spodoptera litura (Fabr.) under the influence of azadirachtin. Indian J Entomol 52, 69-83.

Bora D, Khanikor B (2011) Selective toxicity of Ageratum conyzoides and Ocimum sanctum against Exorista sorbillans (Diptera:Tachinidae) and Antheraea assama (Lepidoptera: Saturniidae). National Academy Science Letters 34, 1\&2, 914.

Bora DS, Khanikor B, Konwar M (2010) Plant extracts for management of UZI fly Exorista sorbillans Wiedemann (Diptera: Tachinidae), in Bioresources For Rural Livelihood. Kulkarni G K, Pandey B N, Joshi B D (eds), pp. 217-224, Narendra Publishing House, New Delhi, India.

Brookman JL, Ratcliffe NA, Rowley AF (1989) Studies on the activation of the phenoloxidase system of insects by bacterial cell wall components. Insect Biochem 19, 47-57.

Dean P, Potter U, Richards EH, Edwards JP, Charnley AK, Reynolds SE (2004) Hyperphagocytic haemocytes in Manduca sexta. J of Insect Physiology 50, 1027-1036.

Denny ERK (1989) Hydrodistillation of oils from aromatic herbs. Perfum. Flavour 14, 57.

El-Aziz NM, Awad HH (2010) Changes in the haemocytes of Agrotis ipsilon larvae (Lepidoptera:Noctuidae) in relation to dimilin and Bacillus thuringiensis infections. Micron 41, 203-209.

Fang Q, Wang L, Zhu J, Li Y, Song Q, Stanely DW, Akhtar Z, Ye G (2010) Expression of immune- response genes in lepidopteran host is suppressed by venom from an ectoperasitoid, Pteromalus puparum. BMC Genomics 11, 484.

Gillespie JP, Kanost MR (1997) Biological mediators of insect immunity. Annu Rev Entomol 42, 611-643.

Gui Z, Hou C, Liu T, Qin G, Li M, Jin B (2009) Effects of insect viruses and pesticides on Glutathione S-Transferase activity and gene expression in Bombyx mori. Journal of Economic Entomology 102, 1591-1598.

Gupta AP (1991) Insect immunocytes and other hemocytes: roles in cellular and humoral immunity, in Immunology of Insects and Other Arthropods. pp. 119, CRC Press, Florida, USA.

Hillyer JF, Christensen BM (2005) Mosquitophenoloxidase and defensin colocalize in melanization in immune responses. J Histochem Cytochem 53, 689-698.

Hiromori H, Nishigaki J (2001) Factor analysis of synergistic effect between the entomopathogenic fungus Metarhizium anisopliae and synthetic insecticides. Appl Entomol Zool 36, 231-236.

Huang Y, Ho SH, Lee HC, Yap YL (2002) Insecticidal properties of eugenol, isoeugenol and methyleugenol and their effects on nutrition of Sitophilus zeamais Motsch. (Coleoptera: Curculionidae) and Tribolium castaneum (Herbst) (Coleoptera: Tnebrionidae). J of Stored Product
Research 38, 403-412.

Jayachandran G, Choudhuri S, Ramkrishnan N (2000) Agedependent changes in phenoloxidase activity of Spodoptera litura (Fabricius) (Lepidoptera: Noctuidae) associated with maturation resistance to nuclear polyhedrosis virus. $\mathrm{J}$ of Entomol Research 24, 97-101.

Kraaijeveld AR, Limentani EC, Godfray HCJ (2001) Basis of the trade-off between parasitoid resistance and larval competitive ability in Drosophila melanogaster. Proceedings of the Royal Society of London, Series B-Biological Sciences 268, 259-261.

Lee CY, Yap HH, Chong NL (1996) Insecticidal toxicity on the adult German cockroach, Blutella germanica (L.) (Dictyoptera: Blattellidae). Malaysian J of Science 17, 1-9.

Ling E, Shiraj K, Kanehatsu R, Kiguchi K (2005) Reexamination of phenoloxidase in larval circulating haemocytes of the silkworm, Bombyx mori. Tissue and Cell 37, 101-107.

Liu S, Niu H, Xiao T, Xue C, Liu Z, Luo W (2009) Does phenoloxidase contributed to the resistance? Selection with butane- fipronil enhanced its activities from diamondback moths. Open Biochemistry Journal 3, 9-13.

Lourenco AP, Zufelato MS, Bitondi MMG, Simöes ZLP (2005) Molecular characterization of a cDNA encoding prophenoloxidase and its expression in Apis mellifera. Insect Biochemistry and Molecular Biology 35, 541-552.

Marmaras VJ, Charalambidis ND, Zervas CG (1996) Immune response in insects: the role of phenoloxidase in defense reactions in relation to melanization and sclerotization, Arch Insect Biochem Physiol 31, 119-133.

Matsumura F (1980) Toxicology of Insecticides. Plenum Press, New York.

Mucklow PT, Ebert D (2003) Physiology of immunity in the water flea Daphnia magna: environmental and genetic aspects of phenoloxidase activity. Physiol Biochem Zool 76, 836-842.

Mucklow PT, Vizoso DB, Jensen KH, Refardt D, Ebert D (2004) Variation in phenoloxidase activity and its relation to parasite resistance within and between populations of Daphnia magna. Proc R Soc Lon B 271, 1175-1183.

Nappi AJ, Sugumaran M (1993) Some biochemical aspects of eumelanin formation in insect immunity; in Insect Immunity. Pathak J P N (eds), 131-148, Oxford \& IBH Publishing Co, New Delhi, India.

Pathak JPN (1993) Cell-mediated defence reactions ininsects, in Insect Immunity, Pathak J P N (eds), 47-58, Oxford \& IBH Publishing Co, New Delhi, India.

Pauwels K, Meester LD, Decaestecker E, Stoks R (2011) Phenoloxidase but not lytic activity reflects resistance against Pasteuria ramose in Daphnia magna. Biol Lett 7, 1156.

Prasada Rao CG, Ray A, Ramamurthy PS (1984) Effect of ligation and ecdysone on total haemocyte count in the tobacco caterpillar, Spodoptera litura (Lepidoptera: Noctuidae). Can J Zool 62, 1461-1463.

Qadri SSH, Narsaiah J (1978) Effect of azadirachtin on the moulting processes of last instar nymphs of Periplaneta 
americana (L.). Indian J Exp Biol 16, 1141-1143.

Rajatileka S, Burhani J, Ranson H (2011) Mosquito age and susceptibility to insecticides, Transactions of the Royal Society of Trop. Medicine and Hygiene 105, 247-253.

Ratcliffe NA, Leonard C, Rowley AF (1984) Prophenoloxidase activation: nonself recognition and cell cooperation in insect immunity. Science 226, 557-559.

Rosenberger CR, Jones JC (1960) Studies on the total blood cell counts of the southern armyworm larva, Prodenia eridenia (Lepidoptera). Ann Entomol Soc Am 53, 351-355.

Schmid MR, Brockmann A, Pirk CWW, Stanley DW, Tautz J (2008) Adult honeybees (Apis mellifera L.) abandon hemocytic, but not phenoloxidase-based immunity. J Insect Physiol 54, 439-444.

Schwarzenbach GA, Ward PI (2007) Phenoloxidase activity and pathogen resistance in yellow dung flies Scathophaga stercoraria. Journal of Evolutionary Biology 20, 2192-2199.

Sharma PR, Sharma OP, Saxena BP (2008) Effect of sweet flag rhizome oil (Acorus calamus) on hemogram and ultrastructure of hemocytes of tobacco armyworm, Spodoptera litura (Lepidoptera: Noctuidae). Micron 39, 544-551.

Shelby KS, Popham JR (2006) Plasma phenoloxidase of the larval tobacco budworm, Heliothis virescens, is virucidal. J of Insect Science 6, 13.

Shelby KS, Adeyeye OA, Okot-Kotber BM, Webb BA (2000) Parasitism-linked block of host plasma melanization. $\mathrm{J}$ of Invertebrate Pathology 75, 218-225.

Shiao SH, Higgs S, Adelman Z, Christensen BM, Liu SH, Chen CC (2001) Effect of prophenoloxidase expression knockout on the melanization of microfilariae in the mos- quito Armigeres subalbatus. Insect Molecular Biology 10, 315-321.

Soderhall HA, Cerenius L (1998) Role of the prophenoloxidase-activating system in invertebrate immunity. Curr Opin Immunol 10, 23-28.

Sugumaran M (2002) Comparative biochemistry of eumelanogenesis and the protective roles of phenoloxidase and melanin in insects. Pigm Cell Res 15, 2-9.

Suhail A, Gogi M D, Arif MJ, Arshad, Rana M, Sarfraz M (2007) Effects of various treatments of azadirachtin, spinosad and bamectin on the haemogram of Coccinella septempunctata L. (Coleoptera: Coccinellidae). Pak Entomol 29(2), 151-163.

Tiwari RK, Pandey JP, Salehi R (2002) Haemopoietic organs and effect of their ablation on total haemocyte count in lemon butterfly, Papilio demoleus L,. Ind Exp Biol 40, 12021205.

Yu SJ (1983) Age variation in insecticide susceptibility and detoxification capacity of fall armyworm (Lepidoptera:Noctuidae) larva. Journal of Econnomic Entomology 76, 219222.

Yu XQ, Jiang H, Wang Y, Kanost MR (2003) Nonproteolytic serine proteinase homologs are involved in prophenoloxidase activation in the tobacco hornworm Manduca sexta. Insect Biochem Mol Biol 33, 197-208.

Zhu LS, Tao NH, Ting X, Bin XC, De LZ, Chun LW (2009) Does phenoloxidase contributed to the resistance? Selection with butane-fipronil enhanced its activities from diamondback moths. Open Biochemistry Journal 3, 9-13. 